\title{
Analysis and Experience Reference of Science and Technology Talent Development Strategy in Developed Countries
}

\author{
An Ran; Meng Jie; Zhang Xiaojing \\ Beijing Institute of Science and Technology \\ Beijing, China \\ anr@bjstinfo.com.cn
}

\begin{abstract}
With the arrival of knowledge economy era, human resource issues have increasingly become public attention. Relying on science and technology innovation is the key to enhance science and technology competitiveness, science and technology human resource is one of the most important resources for national development resources; moreover, it is main body of science and technology activities. All countries have attached great importance to talent strategy research, and formulated a variety of effective policies, regulations and measures to attracting talents, training personnel and employ professionally people.The paper focused on developed countries of the US, UK and Japan as main research objects, generally analyzed main development strategy and successful experience in training innovative science and technology talents, and summarized reference and inspiration for science and technology personnel training in China.
\end{abstract}

Keywords-Science and technology talent; Personnel training and education; Development strategy; Experience reference; Developed countries

\section{INTRODUCTION}

The famous American educator Ralph Taylor promoted science management development in various fields of modern society. He proposed: "Creating activities not only advance science and technology, but also influence all over the world." Nowadays, science and technology development is dominant force of socioeconomic development. Independent innovation ability becomes core of national competitiveness; innovative science and technology personnel construction is key development goal to improve national independent innovation ability.

\section{DEVELOPMENT STRATEGY, TRAINING AND MANAGEMENT OF}

\section{SCIENCE AND TECHNOLOGY TALENTS IN DEVELOPED}

\section{COUNTRIES}

\section{A. The Unite States}

The United States is one of the developed countries in the world. As early as 1960s, it attached great importance to cultivation of science and technology innovation theory and innovation talents. In economic and technological fields, there have a large number of science and technology innovative talents. The US is also a gathering place for outstanding talent in the world. The US's talent development strategy mainly includes scientific and technological talents strategic planning, policy system construction, market mechanism construction, living environment optimization, talent education and training attraction [1].

Specific management and development measures embodied in the following aspects:

1) Emphasizing innovative talents cultivation.The US government persists in priority to education development, ensures law and institution for education development, formulates and implements various preferential policies, attracts talents to serve country development, appeals to outstanding talents in the world for servicing national development. The US government departments pay great attention to personnel training programs and projects, such as United States Navy had established "Young Investigator Program". The government dedicates to establishing education funds and awards in universities and private research institutions, and also trains young researchers who have received a doctorate in recent 5 years [2].The National Science Foundation (NSF) has found a "Presidential Early Career Award for Scientists and Engineers, PECASE ", which grants 200 people per year. The aim is to attract best innovative talents to science and engineering fields.

2) Talents introduction. The US's government laid emphasis on introduction and retention of foreign science and technology innovation talents. The main measures include: the US government has constantly modify immigration law and working permit for foreign science and technology personnel introduction and implement US Permanent Resident green card policy; the government offers merit scholarship to international applicants who demonstrated academic excellence study to participate in science research and 
development in US. Government, companies, individuals and charities establish abundant financial resources research fund to attract innovative talent. In addition, the US has confidence in foreign science and technology personnel, many research projects and cutting-edge technologies research in the field of research are managed by foreign talents. The government engages talents with strong science and technology innovation ability in a high price.

3) Establishing talents training mode.Since 1990s, American universities carried out educational innovation continuously, in order to achieve combination of nature-originated and quantity-orinated activity, science and humanities, teaching and research, and gradually formed a unique innovative talent training mode. Systematic practice system includes engineering practice and entrepreneurship practice, it is also an important driving force in promoting students' independent innovation capacity [3].

\section{B. The United Kingdom}

UK national innovation development strategy. UK is the birthplace of innovative scientific research, the proportion of all kinds of scientific and technological personnel and professionals, various research fields (biology, medicine, information, finance, education, etc.) of science and technology talents and professionals proportion are among the best. Main measures adopted by UK government in innovative talents training and development include (Table 1):

TABLE I. SCIENCE AND TECHNOLOGY PERSONNEL TRAINING IN UK NATIONAL INNOVATION STRATEGY

\begin{tabular}{|c|c|c|c|}
\hline $\begin{array}{c}\text { Pubdate } \\
(y \mathbf{y})\end{array}$ & $\begin{array}{l}\text { National Innovation } \\
\text { Strategy and Policy }\end{array}$ & $\begin{array}{c}\text { Realising } \\
\text { Organization }\end{array}$ & Abstract \\
\hline 1994 & $\begin{array}{l}\text { Realizing our } \\
\text { potential: a strategy } \\
\text { for science, } \\
\text { engineering and } \\
\text { technology }\end{array}$ & Cabinet Office & $\begin{array}{l}\text { After realizing this strategy, the UK government } \\
\text { emphasizes Technology Forecast Plan, "Realizing Our } \\
\text { Potential" Award, Science and Engineering Cooperation } \\
\text { Award, Small Business Research and Technology Award } \\
\text { and Public Awareness Program etc. }\end{array}$ \\
\hline 1998 & $\begin{array}{l}\text { Our Competitive } \\
\text { Future: Building the } \\
\text { Knowledge Driven } \\
\text { Economy }\end{array}$ & $\begin{array}{l}\text { Command of } \\
\text { Her Majesty }\end{array}$ & $\begin{array}{l}\text { The UK Government's White Paper on Competitiveness } \\
\text { sets out the role it and business needs to play in } \\
\text { improving the UK's position. It is of interest in the } \\
\text { technology field because of the great emphasis it puts on } \\
\text { the importance of information technology and } \\
\text { telecommunications. }\end{array}$ \\
\hline 2000 & $\begin{array}{l}\text { Excellence and } \\
\text { Opportunity: A } \\
\text { Science and } \\
\text { Innovation Policy for } \\
\text { the } 21 \text { st Century }\end{array}$ & Cabinet Office & $\begin{array}{l}\text { Through technological innovation and leading basic } \\
\text { research, lead UK's knowledge economy occupies a } \\
\text { favorable position in increasingly fierce competition in } \\
\text { the international market, and further promoting effect in } \\
\text { science, technology, social and economic development. }\end{array}$ \\
\hline 2008 & $\begin{array}{c}\text { Innovation Nation } \\
\text { White paper }\end{array}$ & $\begin{array}{l}\text { Department } \\
\text { for Innovation, } \\
\text { Universities } \\
\text { and Skills, } \\
\text { DIUS }\end{array}$ & $\begin{array}{l}\text { The White Paper, Innovation Nation, sets out the } \\
\text { Government's aim to make the UK the best place in the } \\
\text { world to run an innovative business or public service. }\end{array}$ \\
\hline
\end{tabular}

Excellence talent awards and funding schemes. In order to attract global excellent innovative talents, the UK government has set up a series of personnel incentives and funding programs [4]. According to the different objects of programs, government encourages excellent foreign students to achieve higher education in UK. Furthermore, government welcome foreign outstanding young talents engage in academic research in UK. The following are important talent awards and funding schemes (Table 2). 
TABLE II. MAJOR SCIENCE AND TECHNOLOGY TALENT AWARDS AND FUNDING SCHEMES IN UK

\begin{tabular}{|c|c|c|c|l|}
\hline $\begin{array}{c}\text { Science and } \\
\text { Technology Talent } \\
\text { Awards }\end{array}$ & $\begin{array}{c}\text { Formation } \\
(\mathbf{y r})\end{array}$ & $\begin{array}{c}\text { Awards } \\
\text { frequency }\end{array}$ & Presented by & \multicolumn{1}{|c|}{ Abstract } \\
\hline $\begin{array}{c}\text { Overseas Research } \\
\text { Students Awards } \\
\text { Schemes, ORSAS }\end{array}$ & 1980 & $\begin{array}{c}\text { award } \\
\text { annually }\end{array}$ & $\begin{array}{c}\text { Academy, } \\
\text { Royal Society }\end{array}$ & $\begin{array}{l}\text { An international postgraduate award for } \\
\text { selected foreign country nationals to } \\
\text { undertake research at higher-education } \\
\text { institutions (HEIs) in the United Kingdom. }\end{array}$ \\
\hline $\begin{array}{c}\text { Newton } \\
\text { Fellowships } \\
\text { Scheme }\end{array}$ & 2008 & $\begin{array}{c}\text { award } \\
\text { annually }\end{array}$ & $\begin{array}{c}\text { Universities } \\
\text { UK, UUK }\end{array}$ & $\begin{array}{l}\text { An international postdoctoral award for } \\
\text { selected foreign academics to carry out } \\
\text { research at institutions in the United } \\
\text { Kingdom. }\end{array}$ \\
\hline $\begin{array}{c}\text { Royal Society } \\
\text { Wolfson Research } \\
\text { Merit Award }\end{array}$ & 2000 & $\begin{array}{c}\text { in four annual } \\
\text { rounds, with } \\
\text { up to seven } \\
\text { awards per } \\
\text { round }\end{array}$ & $\begin{array}{c}\text { Royal Society, } \\
\text { Wolfson }\end{array}$ & $\begin{array}{l}\text { Foundation } \\
\text { Awarded for outstanding scientists who } \\
\text { would benefit from a five year salary } \\
\text { enhancement to help recruit them to or retain } \\
\text { them in the UK. }\end{array}$ \\
\hline $\begin{array}{c}\text { Queen Elizabeth } \\
\text { Prize for }\end{array}$ & 2011 & $\begin{array}{c}\text { award } \\
\text { Engineering }\end{array}$ & $\begin{array}{c}\text { The Queen } \\
\text { Elizabeth Prize } \\
\text { Foundation }\end{array}$ & $\begin{array}{l}\text { Awarded for Ground-breaking innovation in } \\
\text { engineering which has been of global benefit } \\
\text { to humanity. }\end{array}$ \\
\hline
\end{tabular}

\section{A. Japan}

Based on consideration of population structure and industrial competitiveness improvement, Japan government regard "knowledge innovation" as fundamental direction of national progress and talent development strategy. By training and attracting practical and innovative talents of science and technology, Japan has been benefited from using global science and technology talent resources to achieve national development [5]. Japan attracts science and technology personnel mainly in the following ways:

1) Developing science and technology talents from elementary education stage.Firstly, Japan government put forward to attach importance to innovative research, emphasize educational fundamental and decisive effect, science and technology personnel training must be grasped from elementary education stage, and cultivate interest and challenge. Secondly, the government would improve higher education system reformation, adjust discipline layout, enhance university students' innovation and capability, and train students to establish a correct outlook and values on life. Finally, government encourages researchers to participate in international academic exchanges to advance internationalization level considerably.

2) Attracting foreign innovative science and technology talents.In order to attracting foreign innovative talents, Japan has formulated regulation of "Foreign Science and Technology Personnel Recruitment System"; it greatly increased absorption and introduction for foreign experts. In 1995, Japan promulgated "Science and Technology Basic Law", "Science and Technology Innovation", and a series of talent development strategy. Some Japanese multinational companies and large enterprises had established foreign research institute abroad to take advantage of global innovative talents, and government had allocated a large amount of funds investment in science research per year [6].

3) Emphasize science and technology cooperation between universities and enterprises.Japan government has proposed to enhance universities and public research institutions innovation capability, and new knowledge has applied to society which was generated in innovation activities. Post-graduate educational mode in Japan further develop talents cultivation mode in cooperation type, industrial laboratory type, industry-government-university combining type were formed, which have unique educational goal, educational way, educational process and organizing management. This model promotes cooperation between industry, government and university, and constructs university innovation system, and accelerates the industrialization research results, forming a virtuous cycle of science and technology innovation. 


\section{SCIENCE AND TECHNOLOGY TALENTS DEVELOPMENT}

\section{TRAINING REVELATIONS}

In 1995, China national leaders issued the "Invigorating the Country through Science, Technology and Education Strategy", attaches great importance to human resources, and reinvigorating China through human resource development strategy. Implementation of the "Thousand Talents Plan" introduced a large number of overseas senior talents, as well as established science research awards programs [7]. The developed countries have experience and practice in science and technology innovative talents development, with studies of their general character, can provide some inspiration and reference for the construction of an innovative country, the cultivation of innovative talents. It can provide some inspiration and reference for China to build innovation oriented country and cultivate science and technology innovative talents [8].

\section{A. Attaching importance to talented capability, and raising talent concept to social value consensus.}

By improving science and technology personnel status, implementing outstanding talent award scheme, and creating a caring talent atmosphere, so that contribution of science researchers have been got society recognized.

\section{B. Providing science research environment for innovative talents.}

China should continue to strengthen construction of domestic science research platform and working environment, and provide science research satisfactory conditions for science and technology researchers to meet their development requirements. Furthermore, personnel awards, aid financially funding and promotion programs implementation will create a comfortable environment.

\section{Improving government's policy and strategic measures for science and technology talents development.}

Firstly, China's government should pay more attention to science and technology innovative talents for national development and economies. Improving innovation strategy formulation and implementation can push forward innovative talents cultivating and training. Secondly, the government should increase investment in research and development funding, attach importance to industry-government-university combining cooperation and scientific and technology achievement and transformation [9]. Finally, it will form distinctive features and functions in national innovation system construction.

\section{Promoting introduction Plan of overseas high-levelled talents and innovative talents cultivation.}

The government should not only develop innovative talents, but also introduce overseas high-levelled talents, and furtherance free circulation of science talents among government research institutions, universities and enterprises.It is necessary to strengthen domestic leading talent, core technology research and development personnel training and innovation team construction in China [10]. It will form a reasonable structure of talent echelon science research, and improve independent innovation capability. At the same time, it is necessary for China's government to adopt a variety of ways to introduce overseas high-level innovative talents, and actively organize and implement talents introduction scheme. Furthermore, the government should encourage innovative science and technology personnel in a multi-level, wide-ranging and full participation in international cooperation in science and technology. We must continue to omni-directional, multilevel and wide-range opening to global world, and support substantive cooperation between China's science and technology talents, international high level research institutes and teams.

\section{CONCLUSION}

On talents attraction development strategy issues, developed countries have committed to creating a fair competitive work and entrepreneurship environment. Furthermore, it is also a significant reason for talents attraction and cultivation. In China, all professions and trades are attaching importance to talents attraction, and the state has also referred to talents to an unprecedented height. China should seize the opportunity to increase cooperation with other countries in education and science research with developed countries through multitudinous science research institutions, colleges and universities to developing, cultivating and attracting innovative talents.

\section{REFERENCE}

[1] Liz Barlow. Talent development: the new imperative? Development and Learning in Organizations: An International Journal, Vol.20 Issue: 3, 2006(6-9).

[2] Mark E. Haskins, George R. Shaffer. "A talent development framework tackling the puzzle", Development and Learning in Organizations: An International Journal, Vol. 24 Issue: 1, 2010(13-16).

[3] Darina Chlebikova, Maria Misankovab , Katarina Kramarova. Planning of Personal Development and Succession, Procedia Economics and Finance, 2015, (26) 249-253.

[4] Malikeh Beheshtifar, Hojat Yossefi Nasab, Mahmood Nekoie.Moghadam. Effective Talent Management: A Vital Strategy to Organizational Success, International Journal of Academic Research in Business and Social Sciences, Vol. 2, No. 12, 2012(227-234).

[5] Ludmila Viktorovna Orlova, Yuri Alekseevich Afonin, Viktor Vladimirovich Voronin. Talent Management and Knowledge: Theory, Methodology, Models, Review of European Studies, Vol. 7, No. 9, 2015,75-82.

[6] Xiaofeng Liu. A review of research on personnel training abroad. Journal of Yunnan Finance and Economics University, Vol.27, No.3, 2012 (50-54). (In Chinese)

[7] Zefang Dong, Xiaohui Wang.Common Characteristics of First-class Foreign Universities' Undergraduate Education and Inspirations, Journal of National Academy of Education Administration, 2014(83-89). (In Chinese)

[8] Qubing Zhang. Experience and Enlightenment of Innovative Talents Training Mode in Foreign Universities, Higher Agricultural Education, 2015(125-127). (In Chinese)

[9] James Sunday KEHINDE. Talent Management: Effect on Organizational Performance, Journal of Management Research, Vol. 4, No. 2, 2012(178-186)

[10] Gloria Ferguson Pobst. Meeting the Challenge of Knowledge Worker Shortages with StrategicTalent Management, American Journal of Management, vol. 14(1-2), 2014(62-66). 